\title{
A holistic organizational behaviour model for organization renewal
}

\author{
M.L. Watkins* \\ Department of Industrial Psychology, University of South Africa, P.O. Box 392, Pretoria, 0001 Republic of South Africa
}

A.L. Barnard

Department of Industrial and Personnel Psychology, Potchefstroom University for C.H.E., Potchefstroom, 2520 Republic of South Africa

Received 19 January 1988; accepted 7 July 1988

\begin{abstract}
There is a need to identify the dependent and independent variables that play a role in organizational renewal. The scientific basis of previous attempts to identify these variables are questionable as they represent the haphazard inclusion of some contextual variables. A holistic view of approaches to organization theory, and its integration with contemporary organization models, makes it possible to scientifically develop and describe a holistic model of organizational behaviour. The model indicates that organizations are composed of human, strategic, technological, control-and-motivation and boundary subsystems. The interaction between these subsystems manifests itself in complex organizational processes which create a climate and culture of shared norms and values. The model identifies those dependent and independent variables which should be considered during renewal attempts. An empirical investigation of the practical value of the model shows that, by using the model as a frame of reference for renewal, positive change can be facilitated in various subsystems and processes. The model can therefore successfully be applied in the practice of organization renewal.
\end{abstract}

Daar bestaan ' $n$ behoefte aan die identifisering van afhanklike en onafhanklike veranderlikes wat tydens organisasievernuwingspogings bestudeer moet word. Die wetenskaplikheid van vorige pogings om hierdie veranderlikes deur middel van modelontwikkeling te identifiseer, staan onder verdenking omdat dit 'n lukraak samevoeging van enkele kontekstuele veranderlikes verteenwoordig. 'n Holistiese beskouing van benaderings tot die organisasieteorie maak dit egter moontlik om 'n holistiese organisasiegedragsmodel te ontwikkel en beskryf. Die model dui aan dat die organisasies saamgestel is uit menslike, tegnologiese, strategiese, beheer-enmotiverings- en koppelvlaksubsisteme. Die interaksie tussen hierdie subsisteme manifesteer in komplekse organisasieprosesse, wat 'n klimaat en kultuur van gedeelde norme en waardes skep. Die model slaag dus daarin om daardie veranderlikes wat tydens organisasievernuwing aandag moet geniet, te identifiseer. 'n Empiriese ondersoek na die toepassingswaarde van die model dui aan dat, wanneer die model as 'n verwysingsraamwerk vir vernuwing gebruik word, dit moontlik is om positiewe verandering in verskeie subsisteme en prosesse teweeg te bring. Die model kan dus suksesvol in die organisasievernuwingspraktyk toegepas word.

- To whom correspondence should be addressed

Organizations are continuously exposed to a dynamic environment with socio-cultural, political and economic forces being exerted upon them (Tichy, 1982: 59). Although a need to adapt to this complex situation gave rise to the implementation of organization renewal strategies (White \& Mitchell, 1976: 163), researchers (Kahn, 1974: 490; Porras \& Roberts, 1980: 163; Roberts \& Porras, 1982: 91) emphasized a necessity to identify those dependent and independent variables which should be studied. Previous attempts to identify these variables by means of organization model-building are questionable due to their haphazard inclusion of contextual variables (White \& Mitchell, 1976: 59). Although Lippitt (1982: 28-29) underscores the importance of a more holistic view of organizations, no holistic organization theory exists (Schein, 1980: 201) and, as a result, no holistic model of organization renewal is currently being pursued (Watkins, 1987: 26). Lippitt claims to be following a holistic approach, however, its scope is restricted to human functioning at different organizational levels. The interaction process between the individual and various formal variables (subsystems) is not fully considered. Besides a need for the scientific development of organizational behaviour models, Kahn (1974) also expresses his concern for closing the gap between organization renewal theory and practice.

The aim of this paper is: (a) to describe a holistic organization behaviour model which was scientifically developed by building upon contemporary approaches to organization theory; and (b) to enhance the integration of organisation theory and practice by means of an empirical investigation of the application of the model. This will be achieved by providing a brief outline of approaches to organization theory and then focusing on the organizational model based upon these approaches. Finally, the application of the model will be empirically tested.

\section{Literature survey}

The development of organization theories is characterized by a nonlinear unfolding of various approaches, including the rational-economic, human relations, self-actualization, complex (Schein, 1980: 52), management styles-and-systems (Barnard, 1979: 2), empirical (Lussato, 1976: 46), social systems and contingency approaches (Scott, Mitchell \& Birnbaum, 1981: 57-58). 
The rational-economic approach is followed by the scientific management school which implements workstudy techniques to improve technology (cf. Taylor, 1947: 18-24) and the administrative school which rely upon strategic activities (eg. planning, organizing, leading and control) to improve effectiveness (cf. Fayol, 1972). This approach was criticized by Sheldon (1923:7), who contended that '.. industry cannot be rendered efficient while the basic factor remains unrecognized that it is primarily human - it is not a mass of machines and technical process - it is a body of men'. Reactions of this nature and Münsterberg's (1913) attempts to measure individual differences in the work situation, gave rise to the human relations approach. This approach was followed by Mayo, Roethlisberger and Dickson whose Hawthorne-experiments showed that workers form informal groups to satisfy their social needs (George, 1972: 150).

The human relations school over-emphasized the importance of group behaviour to organization effectiveness, giving rise to the self-actualization approach (Perrow, 1983: 91). This approach includes Maslow's hierarchy of needs, Herzberg's motivationand hygiene factors, McLelland's nAch theory, Argyris' concern for the discrepancy between individual and organization goals and McGregor's $\mathrm{X}$ and $\mathrm{Y}$ assumptions (Hersey \& Blanchard, 1982: 56-58; Kast \& Rosenzweig, 1981: 253; Argyris, 1957; McGregor, 1960). A strong awareness of individual needs and the enhancement of psychological growth by manipulating the internal organization-environment are found in these theories.

The social systems approach, which is followed by Chester Barnard (1958), Homans (1968), Cyert \& March (1963) and March \& Simon (1958), differs from the previous approaches in that the interaction process between individuals within and outside the organization is studied. In contrast to the rational-economic approach (which views organizations as closed systems), this approach views the organization as an open system which continuously interacts with its environment.

The empirical approach, which is derived from the rational-economic theories, reconsidered many of the assumptions previously made (Lussato, 1976: 71-72). Drucker (1959: 30), a prominent leader of this approach, postulated that the rational-economic assumptions should be replaced by an empirical approach which emphasizes the principles of profit-making, decentralization, broadening the span of control, management-by-objectives and competition. The implementation of management-by-objectives combined with a participative philosophy, provides individuals with an opportunity to satisfy their higher-order needs. The interaction process between individuals and strategic activities (eg. objective formulation and decision-making) is thus emphasized.

The contingency approach concretely describes the interaction process between various subsystems within the organization and the external environment (Scott, Mitchell \& Birnbaum, 1981: 57-58). Prominent followers of this approach include Thompson (1967), who described the interaction process between the organizational strategy, technology and the external environment by means of a technological typology; Burns \& Stalker (1961), who described the interaction process between organizational technology and strategy by proposing a mechanistic structure for organizations with stable technology and an organic structure for organisations with dynamic technology; and Lawrence \& Lorsch (1969), who described the interaction process between individuals and the organizational strategy in terms of differentiation and integration.

The roots of the management styles-and-systems approach are found in Stogdill's attempts to identify leadership traits and Kurt Lewin's hypothesis that behaviour is the result of the interaction between environmental influences and individual traits (Stogdill, 1974: 74-75; Gilmer, 1971: 214). This approach gained further momentum when the Michigan and Ohio researchers (eg. Likert, Blake and Mouton) attempted to optimize the relationship between leaders and followers by prescribing optimal leadership styles.

According to Schein (1980: 87-92), the complex approach can be subdivided into the following theoretical perspectives:

(a) The career development perspective, which is followed by inter alia Schein, Super and Holland. These theories attempt to help individuals to avoid frustration and dissatisfaction by correctly choosing a career.

(b) The situational perspective, which is followed by inter alia Fiedler, (1980), Reddin (1973) and Hersey \& Blanchard (1982). These theorists attempt to optimize the relationship between managers and subordinates by changing leader behaviour whilst considering the intervening influence of situational variables.

(c) The work value perspective, which includes Katz and Van Maanen's loci of work satisfaction ( $c f$. Schein, 1980: 87-88) and the expectancy theory which is discussed extensively by Porter, Lawler \& Hackman (1981: 37-65) and Nadler, Hackman \& Lawler (1979: 28-37). In contrast to any of the perspectives or approaches previously discussed, this perspective attempts to describe the role of intrapersonal variables in work motivation and satisfaction.

(d) The organizational perspective, which is followed by inter alia Schein (1980: 44) who emphasized the role of norms, power and authority as important determinants of organizational behaviour.

\section{A holistic organizational behaviour model}

A holistic view of the approaches to organization theory in terms of organization subsystems and the processes which are studied, is illustrated in Figure 1. This indicates that organization theories pertain to the study ofhuman, strategic, and technological subsystems, as well as the interactions between them. Although this classification only partly describes the holistic nature of organizational functioning, a synthesis of Figure 1 with various contemporary organization models (Margulies \& 
Raia, 1978: 12; Friedlander \& Brown, 1974: 9-21; Seiler, 1972: 256-259; Klein \& Ritti, 1984: 37-42; French \& Bell, 1984: 56-59; Nadler \& Tushman, 1980: 35-51; Lawrence \& Lorsch, 1969: 9-19), makes it possible to propose a holistic model of organizational behaviour. This model is illustrated in Figure 2.

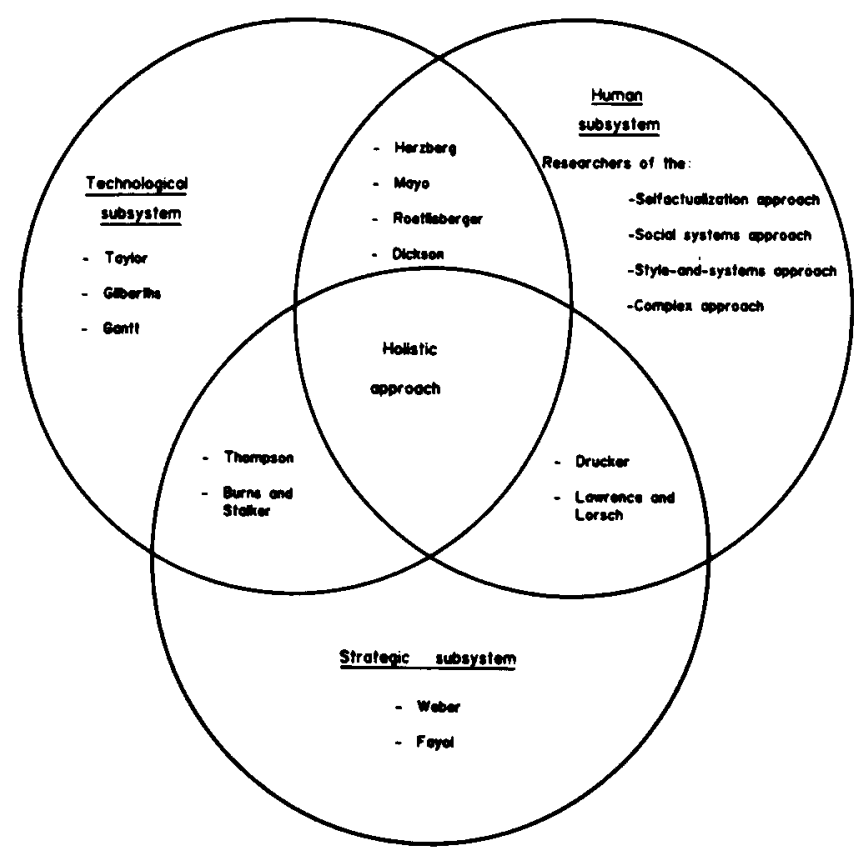

Figure 1 A holistic view of approaches to organization theory
Figure 2 indicates organizational behaviour determined by the following interacting subsystems:

(a) A human subsystem, which is formed by individuals who join the organization to fulfil certain needs (Nadler \& Tushman, 1980: 44; Beer, 1980: 36). The interaction between individuals manifests itself in the forming of groups which function interdependently to attain organizational goals (Lawler, Nadler \& Cammann, 1980: 147). A dominant coalition which consists of a few individuals with significant influence upon the organization's mission and practices, emerges from the group-forming processes (Katz \& Kahn, 1978: 240-241; Kotter, 1978: 20).

(b) A strategic subsystem, which can be subdivided in strategic planning activities (Wheelen \& Hunger, 1984: 3-4), short, medium and long-term objectives (Klein \& Ritti, 1984: 453) and an organizational structure which enhances effective communication and the optimal utilization of skills (Duncan, 1979: 59-60).

(c) A technological subsystem, which is formed by work processes, tasks, subtasks (French \& Bell, 1984: 57) and the skills needed to perform those tasks (Klein \& Ritti, 1984: 101).

(d) A control-and-motivation subsystem which controls various organizational activities and motivates behaviour (Kotter, 1978: 16-17). Remuneration structures, for example, serve as mechanisms that control the fairness of financial

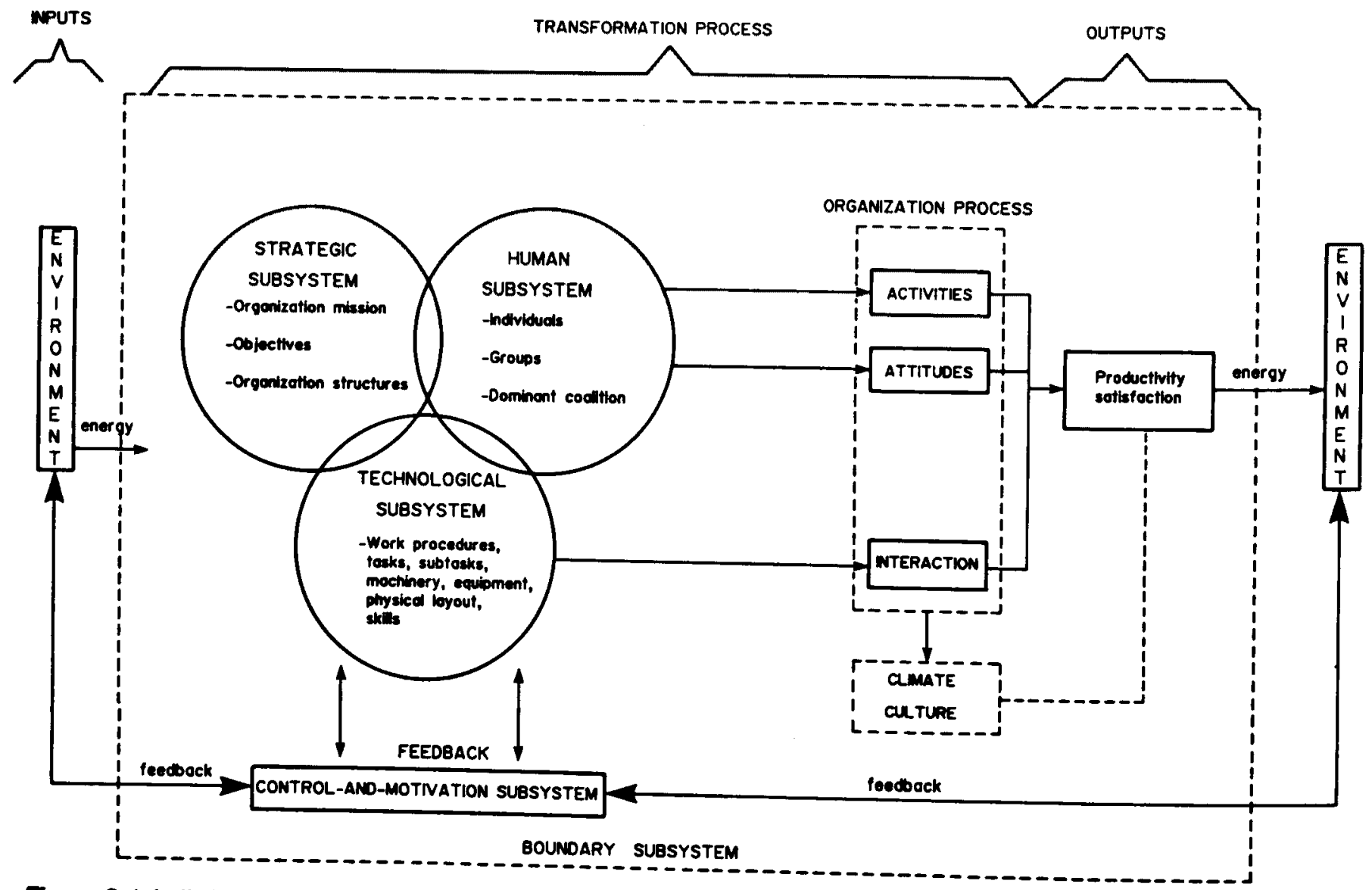

Figre 2 A holistic model of organization renewal 
incentives. Considering Adams's equity theory, these structures are also able to motivate behaviour in the direction of goal attainment.

(e) A boundary subsystem, which forms an interface between the organization and it's environment. The main function of this subsystem is to filter energy and information to and from the organization (cf. Watkins, 1987: 50-53).

The interaction between the subsystems manifests itself in complex organizational processes which can broadly be categorized in terms of activities (eg. management and employee activities), attitudes, and the nature of interpersonal interaction. An organizational climate that can be described as cold, relaxed, conservative, etc. emerges from interpersonal encounters (Porter, et al., 1981: 456), and forms a culture of shared norms, values and assumptions (Westrum \& Samaha, 1984; Margulies \& Raia, 1978).

These complex processes significantly influence the quality and quantity of the organization's outputs as well as the work satisfaction experienced by its members.

\section{Methodology for applying the model}

The contextual variables included in the holistic model served as a frame of reference for the implementation of an organization renewal strategy at the procurementdivision of a manufacturing firm. The division's objectives are to: (a) identify suppliers who are able to provide components that can be used to assemble the end products, after which a buying-contract is negotiated; and (b) ensure that the components meet the quality standards set by the organization. The sample which was available for study included all the managers $(N=7)$, supervisors $(N=24)$ and subordinates $(N=$ $110)$ employed in the division.

The renewal strategy was implemented in three phases, namely a diagnostic phase, during which organizational problems were explored, the implementation of interventions, and the evaluation of the change strategy.

Due to a lack of instruments for measuring the variables in the model, an organization diagnostic questionnaire was developed and validated by means of factor analysis and a reliability study ( $c f$. Watkins, 1987: 140). Although the questionnaire proved to be reliable (Alpha Chronbach $r=0,95$ ), the factor analysis indicated that the instrument cannot measure all the variables included in the holistic model. The questionnaire was therefore combined with the 'dimensions of organisation functioning' developed by Boshoff (1982), and the 'organisation priorities survey' developed by Woodcock \& Francis (1981). The extent to which the model is measured by combining these questionnaires is illustrated in Table 1.

Table 1 shows that although a combination of instruments do not make it possible to fully diagnose every subsystem of the model, some progress in this direction is made. During the diagnostic phase the 'dimensions of organisation functioning' and 'organisation priorities survey' were administered at the management and supervisory levels and the 'organization diagnostic questionnaire' was administered at the worker level. It is beyond the scope of this article to fully discuss the modus operandi which was followed during the diagnostic phase, therefore only the most important organizational problems that were identified, are listed below:

(a) Strategic subsystem:

- Ojectives were unclear at the managerial and supervisory levels

- Objectives were not communicated to all hierarchical levels

- Worker skills were inadequately utilized

Table 1 Subsystems and processes measured

\begin{tabular}{|c|c|c|c|c|c|}
\hline $\begin{array}{l}\text { Measurement } \\
\text { instrument }\end{array}$ & Strategic & Human & Technological & $\begin{array}{l}\text { Control-and- } \\
\text { motivation }\end{array}$ & Processes \\
\hline $\begin{array}{l}\text { Diagnostic } \\
\text { questionnaire }\end{array}$ & - Strategy & - Work satisfaction & - Technology & & $\begin{array}{l}\text { - Communication between supervisor and } \\
\text { subordinate } \\
\text { - Relationship between manager and } \\
\text { subordinate }\end{array}$ \\
\hline Priorities survey & $\begin{array}{l}\text { - Clarity of } \\
\text { objectives } \\
\text { - Organization } \\
\text { structure }\end{array}$ & & $\begin{array}{l}\text { - Efficiency of } \\
\text { work } \\
\text { - Development of } \\
\text { skills }\end{array}$ & & $\begin{array}{l}\text { - Openness and support } \\
\text { - Teamwork }\end{array}$ \\
\hline $\begin{array}{l}\text { Dimensions of } \\
\text { organization } \\
\text { functioning }\end{array}$ & $\begin{array}{l}\text { - Clarity of } \\
\text { objectives and } \\
\text { standards } \\
\text { - Utilization of } \\
\text { skills }\end{array}$ & & & $\begin{array}{l}\text { - Control } \\
\text { processes } \\
\text { - Performance } \\
\text { review }\end{array}$ & $\begin{array}{l}\text { - Teamwork } \\
\text { - Interaction } \\
\text { - Commitment } \\
\text { - Decision making } \\
\text { - Handling of conflict } \\
\text { - Adaptability } \\
\text { - Time management } \\
\text { - Planning }\end{array}$ \\
\hline
\end{tabular}


- Communication of policy to the workers was inefficient

(b) Human subsystem:

- Workers disliked their work

- Workers enjoyed little participation during the planning of work methods

(c) Technological subsystem:

- Inefficient work methods prevailed

- Workers lacked the skills to perform their work adequately

- Too much information was unnecessarily duplicated

(d) Control-and-motivation subsystem:

- A lack of effective control existed

- Work results were inadequately reviewed

(e) Organizational processes:

- Problems were experienced with planning activities

- Time-management was inefficient

- Supervisors failed to make full use of the workers' ideas

- A lack of communication at the supervisory and managerial levels existed

(f) Organizational outputs:

- The quality of the components supplied to the organization failed to meet the quality standards set by the organization.

During the intervention phase, the following actions were taken to address the identified problem areas:

(a) A management-by-objectives programme was implemented in an attempt to solve the problems identified in the strategic subsystem (unclear objectives and work standards), the control-andmotivation subsystem (review and control) and the organizational processes (communication, planning activities and time management).

(b) The situational leadership seminar (Hersey \& Blanchard, 1980) was presented to the managers and supervisors to equip them with skills to apply appropriate leadership styles in different interpersonal situations, including performance review.

(c) The managers and supervisors were trained in the identification of training needs, the development of training courses and the evaluation of training. The purpose of the training was to enable the managers and supervisors to train (a) subordinates in workrelated skills and (b) suppliers in skills related to effective quality control. It was therefore possible to indirectly intervene in the environment.

(d) The company policy and written management philosophy was adapted to fit the objectives which were formulated during the management-byobjectives programme, and a written copy was made available to all employees.

(e) The supervisors were assigned to investigate and improve defective work procedures in the division.

Organization renewal is a long-term effort. The evaluation phase therefore followed one year after the interventions were implemented. Change can best be evaluated by means of a research design in which experimental and control groups are compared before and after a specific treatment. Organization renewal strategies, however, are implemented in real situations which makes it difficult, if not impossible, to distinguish experimental and control groups. Organization renewal therefore, finds it difficult to withstand the rigorous testing required of any scientific field of study (Terpstra, 1981: 25; Blumberg \& Pringle, 1983: 417). In view of this problem, a pre-post study without control groups was performed during which the questionnaires already referred to, were used twice. After administering the questionnaires, the one-tailed significance of differences between pre and post measures was determined by means of the $t$ test for small dependent samples at the managerial level ( $c f$. Levin, 1973) and large dependent samples at the supervisory level ( $c f$. Du Toit, 1975). Due to the disadvantages of this design, the effect size and power efficiency of the interventions (the level to which results are generalizable) were also determined. Cohen (1977: 51) points out that effect size is derived from the formula:

$d=\frac{M a-M b}{\sqrt{1-r}}$

where $d=$ effect size index for $t$ tests between means; $M a, M b=$ population means expressed in raw unit; and $r=$ the correlation between the pre and post measures.

For the purpose of this study, Cohen's criteria for effect size were accepted, namely 0,2 (a small effect size), 0,5 (a medium effect size) and 0,8 (a large effect size). To reduce the occurrence of Type 1 errors, the Bonferroni method (Morrison, 1976) was applied, as a result of which the acceptable significant level was set at 0,005 . The power efficiency of the measurement was derived from statistical tables provided by Cohen (pp. 28-39). For example, an effect size of 0,2 with power efficiency of 0,9 at the 0,01 level shows that, should the experiment be repeated with other samples of the same size, the researcher can expect to measure the same small effect size (at the 0,01 level) in $90 \%$ of the cases. The power efficiency figures in Table 2 therefore provide indices of the generalizability of the results.

Although questionnaires contain important 'soft' criteria for the measurement of change, Armenakis, Feild \& Holley (1976: 1149-1150) and Terpstra (1981: 26) contend that there exists an urgent need for the evaluation of change by means of 'hard' criteria. A time series design as proposed by Armenakis \& Feild (1975), was therefore employed to study the effect of the interventions on: (a) absenteeism; and (b) the extent to which the quality of the components supplied to the organization, improved.

\section{Findings}

The results of the study are summarized in Table 2 and Figures 3 and 4.

\section{Strategic subsystem}

Both the managers and the supervisors felt that objectives were significantly clearer after the 
Table 2 Significance, size and power efficiency of treatment effects

\begin{tabular}{|c|c|c|c|c|c|c|c|c|c|}
\hline \multirow{2}{*}{$\begin{array}{l}\text { Organizational } \\
\text { subsystem }\end{array}$} & \multirow{2}{*}{$\begin{array}{l}\text { Organizational } \\
\text { level }\end{array}$} & \multirow{2}{*}{$\begin{array}{l}\text { Measurement } \\
\text { instrument }\end{array}$} & \multirow[b]{2}{*}{ Criterion } & \multicolumn{2}{|c|}{ Means } & \multirow[b]{2}{*}{$t$ value } & \multirow{2}{*}{$\begin{array}{c}\text { Effect size } \\
\quad a\end{array}$} & \multicolumn{2}{|c|}{ Power efficiency } \\
\hline & & & & Pre & Post & & & 0,01 & 0,05 \\
\hline \multirow[t]{7}{*}{$\begin{array}{l}\text { Strategic } \\
\text { subsystem }\end{array}$} & Managerial & Dimensions & $\begin{array}{l}\text { Clarity of } \\
\text { objectives }\end{array}$ & 5,57 & 7,28 & $2,30^{a}$ & $0,39(S)$ & 0,19 & 0,46 \\
\hline & & & Work standards & 4,28 & 6,14 & 1,17 & $0,98(\mathrm{~L})$ & 0,30 & 0,60 \\
\hline & & $\begin{array}{l}\text { Priorities } \\
\text { survey }\end{array}$ & $\begin{array}{l}\text { Communication } \\
\text { of objectives }\end{array}$ & 13,43 & 11,00 & 1,73 & $0,79(\mathrm{M})$ & 0,19 & 0,46 \\
\hline & Supervisory & Dimensions & $\begin{array}{l}\text { Clarity of } \\
\text { objectives }\end{array}$ & 4,86 & 6,02 & $2,57^{\circ}$ & $0,78(\mathrm{M})$ & 0,64 & 0,86 \\
\hline & & & Work standards & 4,63 & 6,21 & $3,46^{b}$ & $0,84(\mathrm{~L})$ & 0,64 & 0,90 \\
\hline & & $\begin{array}{l}\text { Priorities } \\
\text { survey }\end{array}$ & $\begin{array}{l}\text { Communication } \\
\text { of objectives }\end{array}$ & 12,88 & 12,08 & 1,07 & $0,23(\mathrm{~S})$ & 0,05 & 0,18 \\
\hline & Worker level & $\begin{array}{l}\text { Diagnostic } \\
\text { questionnaire }\end{array}$ & $\begin{array}{l}\text { Clarity of } \\
\text { company policy }\end{array}$ & 2,81 & 3,67 & $3,81^{b}$ & $0,58(\mathrm{M})$ & 0,64 & 0,86 \\
\hline \multirow[t]{3}{*}{$\begin{array}{l}\text { Human } \\
\text { subsystem }\end{array}$} & Worker level & $\begin{array}{l}\text { Diagnostic } \\
\text { questionnaire }\end{array}$ & $\begin{array}{l}\text { Attractiveness } \\
\text { of work }\end{array}$ & 1,91 & 1,59 & 0,11 & 0,03 & - & - \\
\hline & & & $\begin{array}{l}\text { Enjoyment of } \\
\text { work }\end{array}$ & 2,43 & 2,69 & 1,11 & 0,17 & - & - \\
\hline & & & Autonomy & 2,85 & 3,19 & 1,57 & $0,24(S)$ & 0,08 & 0,15 \\
\hline \multirow{4}{*}{$\begin{array}{l}\text { Control-and- } \\
\text { motivation } \\
\text { subsystem }\end{array}$} & Managerial & Dimensions & Effective control & 4,57 & 6,29 & $2,11^{\wedge}$ & $0,90(\mathrm{~L})$ & 0,25 & 0,53 \\
\hline & Supervisory & & Review of results & 5,33 & 7,42 & $2,19^{n}$ & $1,31(\mathrm{~L})$ & 0,95 & 0,96 \\
\hline & & & Effective control & 4,92 & 7,04 & $4,62^{b}$ & $1,01(\mathrm{~L})$ & 0,85 & 0,96 \\
\hline & & & Review of results & 5,40 & 7,29 & $5,48^{b}$ & $1,25(\mathrm{~L})$ & 0,45 & 0,75 \\
\hline \multirow[t]{6}{*}{$\begin{array}{l}\text { Technological } \\
\text { subsystem }\end{array}$} & Managerial & $\begin{array}{l}\text { Priorities } \\
\text { survey }\end{array}$ & $\begin{array}{l}\text { Efficiency of } \\
\text { Work procedures }\end{array}$ & 12,14 & 11,00 & 1,29 & $0,22(\mathrm{~L})$ & 0,05 & 0,35 \\
\hline & & & $\begin{array}{l}\text { Work-related } \\
\text { skills }\end{array}$ & 12,71 & 14,00 & 1,26 & $0,22(S)$ & 0,03 & 0,10 \\
\hline & Supervisory & & $\begin{array}{l}\text { Efficiency of } \\
\text { Work procedures }\end{array}$ & 11,95 & 11,5 & 2,01 & 0,17 & - & - \\
\hline & & & $\begin{array}{l}\text { Work-related } \\
\text { skills }\end{array}$ & 11,63 & 11,87 & 1,45 & 0,09 & - & - \\
\hline & Worker level & $\begin{array}{l}\text { Diagnostic } \\
\text { questionnaire }\end{array}$ & $\begin{array}{l}\text { Duplication of } \\
\text { information }\end{array}$ & 2,67 & 3,48 & $2,07^{\mathrm{a}}$ & $0,45(S)$ & 0,38 & 0,65 \\
\hline & & & $\begin{array}{l}\text { Efficiency of } \\
\text { equipment }\end{array}$ & 2,36 & 3,31 & $3,44^{b}$ & $0,53(M)$ & 0,48 & 0,76 \\
\hline \multirow{9}{*}{$\begin{array}{l}\text { Organization } \\
\text { process }\end{array}$} & Managerial & Dimensions & Planning process & 5,10 & 6,28 & 1,06 & $0,31(S)$ & 0,13 & 0,67 \\
\hline & & & Time management & 4,18 & 6,85 & 1,61 & $0,37(S)$ & 0,54 & 0,83 \\
\hline & & & Communication & 6,14 & 8,14 & $2,97^{\mathrm{a}}$ & $0,80(L)$ & 0,23 & 0,55 \\
\hline & Supervisory & & Planning process & 5,04 & 6,75 & $3,55^{b}$ & $0,89(\mathrm{~L})$ & 0,74 & 0,91 \\
\hline & & & Time management & 5,04 & 6,46 & $3,06^{\mathrm{a}}$ & $0,70(\mathrm{M})$ & 0,50 & 0,77 \\
\hline & & & Communication & 6,14 & 8,14 & $2,97^{a}$ & $0,80(\mathrm{~L})$ & 0,23 & 0,55 \\
\hline & Worker level & $\begin{array}{l}\text { Diagnostic } \\
\text { questionnaire }\end{array}$ & $\begin{array}{l}\text { Utilization of } \\
\text { workers' ideas }\end{array}$ & 2,79 & 3,24 & $2,0^{\circ}$ & $0,31(S)$ & 0,16 & 0,39 \\
\hline & & & $\begin{array}{l}\text { Extent to which } \\
\text { workers are } \\
\text { allowed to apply } \\
\text { own ideas }\end{array}$ & 2,67 & 2,45 & 0,81 & 0,12 & - & - \\
\hline & & & $\begin{array}{l}\text { Fulfilment of } \\
\text { workers' expectations }\end{array}$ & 2,88 & 3,31 & $1,83^{\circ}$ & $0,28(S)$ & 0,16 & 0,38 \\
\hline
\end{tabular}

a $p<0,005 ;{ }^{b} p<0,001$

$a-S=$ small $\mathbf{M}=$ medium; $L=$ large. See text 


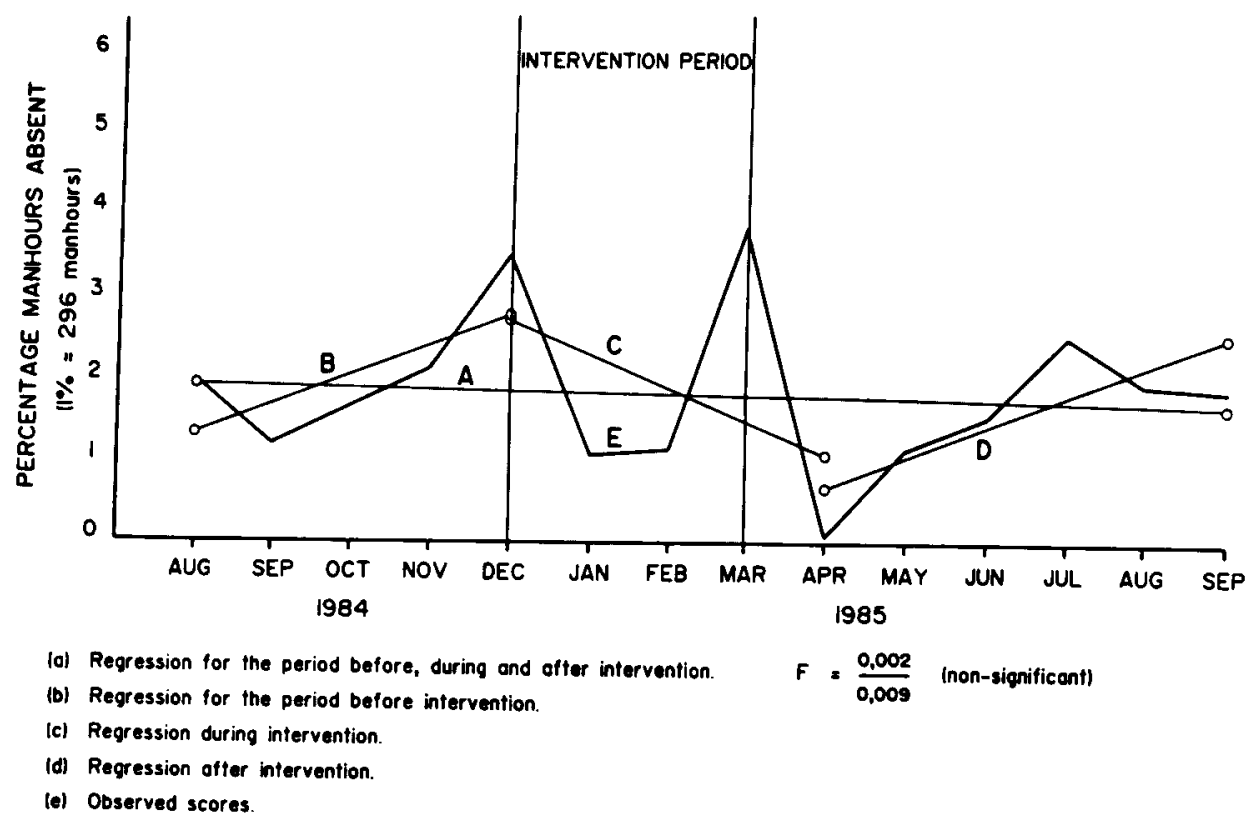

Figure 3 Absenteeism before, during and after intervention

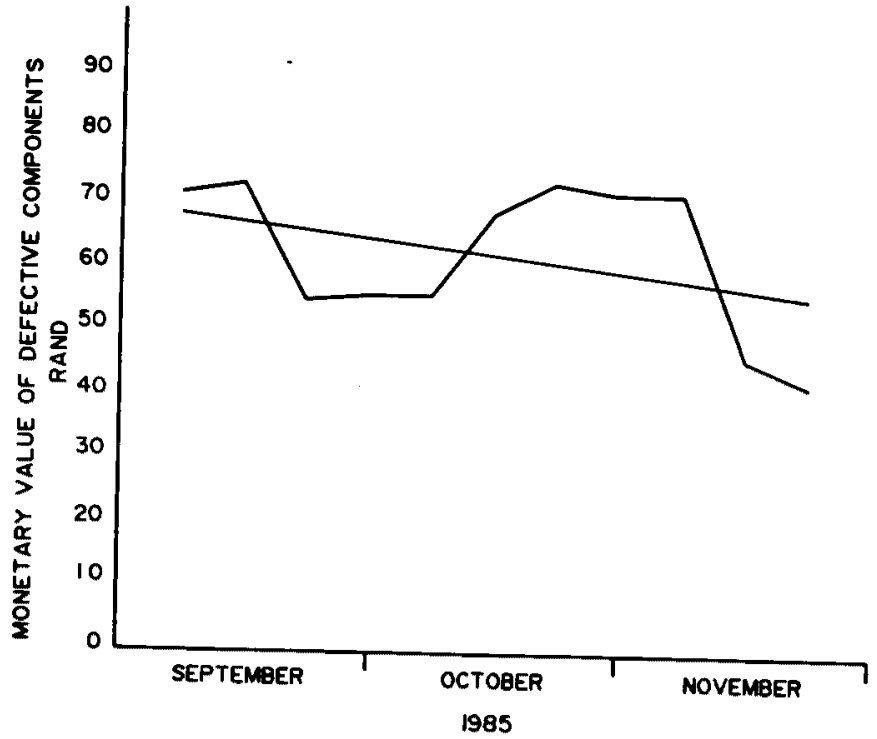

Figure 4 Trend in monetary value of defective components

intervention phase. A small effect size was measured at the managerial level, whereas a medium effect was measured at the supervisory level. Although the work standards seem to be significantly more measurable only at the supervisory level, large effect sizes were measured at both levels. Although these results indicate positive change in the strategic subsystem, the priorities survey revealed that the communication of objectives did not significantly improve. After the intervention phase, the diagnostic survey showed that company policy was significantly clearer with a medium effect size at the worker level.

\section{Human subsystem}

After the interventions, the organization diagnostic questionnaire measured low scores on the attractiveness of the work content, enjoyment of work and the amount of autonomy experienced in the work situation. Interviews conducted to determine the underlying reasons for these findings, revealed that the personnel in the division are technicians with expert knowledge of the products which are manufactured. Although knowledge of the products is an important prerequisite for effective performance, these employees lacked the high level interpersonal skills to effectively negotiate contracts. Although it was part of the management's strategic plan to optimize the procurement function within the organization by employing personnel with expert knowledge of the product, the interpersonal situation in which these employees are engaged created some dissatisfaction. In reaction to these findings, the recruitment division of the organization was further instructed to adapt its selection batteries accordingly.

\section{Control-and-motivation subsystem}

This subsystem showed significant change in all the dimensions measured. At both the managerial and supervisory levels review of work results significantly improved and the effect sizes proved to be large at both levels. These findings can probably be ascribed to the fact that work standards were significantly more measurable after the intervention phase. The control process within the division also significantly improved at both levels, with large effect sizes.

\section{Technological subsystem}

This subsystem showed no significant improvement in any of the dimensions measured at the managerial and supervisory levels. Although the supervisors were assigned to improve work procedures, further interviews revealed that the other interventions were too time consuming to allow them to do so. Although a course in training skills was presented to the managers and supervisors to enable them to train their subordinates, 
the priority survey failed to measure a significant improvement in the subordinates' skills to do their work. This finding can probably be ascribed to the fact that no further assistance was given to implement the acquired skills. At the worker level, the diagnostic survey showed significant improvement with regard to the duplication of information, with a small effect size, and the efficiency of equipment with a medium effect size.

\section{Organizational processes}

After the intervention, several organizational processes showed significant improvement. The efficiency of planning activities increased at the supervisory level with a large effect size. Although time management improved significantly at the supervisory level with a medium effect size, no significant change was measured at the managerial level. Interviews with the job incumbents revealed that the supervisors determined priority actions after the diagnostic phase, whereas this was not the case at the managerial level. These differences in results inspired the managers to determine priority actions afterwards.

Interpersonal communication improved significantly at the managerial and supervisory levels with large effect sizes at both levels. The extent to which the supervisors used the workers' ideas increased significantly, but the effect size proved to be small. The extent to which workers' expectations are fulfilled increased significantly, although only a small effect size was measured.

\section{Organization outputs}

Figure 2 shows a sharp decrease in absenteeism directly after the intervention period. Although the absenteeism rate declined in the short term, it increased again later. This finding can possibly be ascribed to a lack of conscious effort on the side of the managers and supervisors to maintain the renewal process. The authors believe that a significant decrease in absenteeism would otherwise have been meausured.

The findings regarding the monetary value of the products which failed to meet quality standards (Figure 3) clearly show a declining trend after the intervention phase. Although an absence of data made it impossible to reach conclusions about pre-post differences, it seems that the renewal attempt positively influenced the quality of components supplied to the organization. This trend can most probably be ascribed to the managers' and supervisors' concious effort to train suppliers in skills related to quality control.

\section{Conclusions}

A holistic model that builds upon contemporary approaches to organization theory, makes it possible to identify various dependent and independent variables that should be considered during attempts at organization renewal. The model indicates that organizational behaviour is determined by complex interactions between various formal subsystems which manifests itself in the forming of organizational climate and culture. It was not possible to measure all the variables in the model. The model nevertheless seems to provide a frame of reference for implementing positive change in spesific problematic organizational subsystems and processes.

The evaluation phase of the study showed that the renewal attempt failed to bring about significant improvement at all levels in every subsystem. This finding may be largely due to problems experienced with the implementation of the interventions rather than the specific approach which was followed. The results of the study should be viewed with caution due to problems experienced to effectively control the confounding influence of extraneous variables. It nevertheless seems that the holistic model serves as a useful analytical tool for implementing organization renewal strategies. The model also enhances the conceptualization of complex organisational dynamics, which makes it possible to concretely describe the interaction process between various organizational subsystems. This approach differs from other approaches to renewal in that the organization is viewed as a multi-functional unit with interdependent parts.

The problems experienced with the research shows that further investigation is needed to fully measure the dimensions of the proposed organization model. There also exists an urgent need for a research design which can be utilized to effectively control the contaminating effect of extraneous variables in real situations.

\section{References}

Argyris, C. 1957. Personality and organization. New York: Harper and Row.

Armenakis, A.A. \& Feild, S. 1975. Evaluation of nonindependent criterion measures. Personnel psychol., vol.28, 39-44.

Armenakis, A.A., Feild, H.S. \& Holley, W.H. 1976. Guidelines for overcoming empirically identified evaluation problems of organizational development change agents. Human rel., vol.29, 1147-1161.

Barnard, A.L. 1979. Werksmotivering. Potchefstroom: Potchefstroom University for C.H.E.

Barnard, C.I. 1958. The functions of the executive. Cambridge, Mass.: Harvard University.

Beer, M. 1980. Organization change and development: $a$ systems view. Santa Monica, Calif.: Goodyear.

Blumberg, M. \& Pringle, C.D. 1983. How control groups can cause loss of control in action research: the case of Rushton Coal Mine. J. Appl. Behav. Sci., vol.19, 409-425, Nov.

Boshoff, A.B. 1982. Dimensions of organizational functioning. Pretoria: University of Pretoria.

Burns, T. \& Stalker, G.M. 1961. The management of innovation. London: Tavistock.

Cohen, J. 1977. Statistical power analysis for the behavioural sciences. New York: Academic Press. 
Cyert, R.M. \& March, J.G. 1963. A Behavioral theory of the firm. New York: Prentice-Hall.

Drucker, P.F. 1959. Potentials of management science. Harv. Bus. Rev., vol.37, 1-67, Jan.

Duncan, R. 1979. What is the right organization structure? Organ. Dynamics, vol.7, 59-80, Winter.

Du Toit, J.M. 1975. Statistiese metodes. Stellenbosch: Kosmo.

Fayol, H. 1972. General and industrial management. New York: Pittman.

Fiedler, F. 1980. The contingency model: new directions for utilization. In: Koontz, H., O’Donnell, C., Weihrich, H., (eds.), Management: a book of readings. 5th Edition, New York: McGraw-Hill, p.541-548.

French, W.L. \& Bell, C.H. 1984. Behavioral science interventlons for organization improvement. New York: Prentice-Hall.

Friedlander, F. \& Brown, L.D. 1974. Organization development. In: Rosenzweig, M.R. \& Porter, L.W., (eds.), Annual review of psychology. vol.25, 313-342.

George, C.S. 1972. The History of management thought. 2nd Edition, Englewood-Cliffs: Prentice-Hall.

Gilmer, B. Von H. 1971. Industrial and organizational psychology. Tokyo: McGraw-Hill.

Hersey, P. \& Blanchard, K.H. 1980. The essentials of situational leadership. Escondido, Calif.: Leadership Studies.

Hersey, P. \& Blanchard, K.H. 1982. Management of organizational behaviour: utilizing human resources. 4th Edition, New Jersey: Prentice-Hall.

Homans, G. 1968. The human group. London: Routledge and Kegan Paul.

Kahn, R.L. 1974. OrganizationaI development: some problems and proposals. J. Appl. Behav. Sci., vol.10, 485-502.

Kast, F.E. \& Rosenzweig, J.E. 1981. Organization and management: a systems and contingency approach. 3rd Edition, Tokyo: McGraw-Hill.

Katz, D. \& Kahn, R.L. 1978. The social psychology of organizations. 2nd Edition, New York: John Wiley.

Klein, S.M. \& Ritti, R.I. 1984. Understanding organizational behaviour. 2nd Edition, Boston, Mass.: Kent.

Kotter, J.P. 1978. Organizational dynamics: diagnosis and intervention. Reading, Mass.: Addison-Wesley.

Lawler, E.E., Nadler, D.A. \& Cammann, C. 1980. Organizational assessment: perspectives on the measurement of organization behaviour and the quality of work life. New York: John Wiley.

Lawrence, P.R. \& Lorsch, J.W. 1969. Developing organizations: diagnosis and action. Reading, Mass.: Addison-Wesley.

Levin, J. 1973. Elementary statistics in social research. New York: Harper and Row.

Lippitt, G.L. 1982. Organization renewal: a holistic approach to organization development. Englewood Cliffs: Prentice-Hall.

Lussato, B. 1976. A critical introduction to organization theory. London: McMillan.

March, J.G. \& Simon, H.A. 1958. Organizations. New York: John Wiley.
Margulies, N. \& Raia, A.P. 1978. Conceptual foundations of organization development. New York: McGraw-Hill.

McGregor, D. 1960. The human side of enterprise. Tokyo: McGraw-Hill.

Morrison, E.L. 1976. Multivariate statistics. New York: John Wiley.

Münsterberg, H. 1913. Psychology and industrial efficiency. New York: Houghton Mifflin.

Nadler, D.A., Hackman, J.R., \& Lawler, E.E. 1979. Managing organizational behaviour. Boston: Little Brown.

Nadler, D.A. \& Tushman, M.L. 1980. A model for diagnosing organizational behaviour. Organ. Dynamics, vol.9, 35-51, Autumn.

Nadler, D.A. \& Tushman, M.L. 1980. A model for diagnosing organizational behaviour. Organ. Dynamics, vol.9, 35-51, Autumn.

Perrow, C. 1983. The short and glorious history of organizational theory. In: Hackman, J.R., Lawler, E.E., Porter, L.W., (eds.), Perspectives on behaviour in organizations. New York: McGraw-Hill, p.90-96.

Porras, N.C. \& Roberts, J.I. 1980. Toward a typology of organization development research. J. Occup. Behav., vol.1, 163-179.

Porter, L.W., Lawler, E.E., Hackman, J.R. 1981. Behaviour in organizations. Auckland: McGraw-Hill.

Reddin, W.J. 1973. The 3-D Management Style theory: A typology based on task and relationships orientation. In: French, W.L. \& Hellriegel, D. (eds.), Personnel management: fields in transition. Boston: Houghton \& Mifflin, p. 341-344.

Roberts, N.C. \& Porras, J.I. 1982. Progress in organization development research. Group Organ. Stud., vol.7, 91-116, Mrt.

Schein, E.H. 1980. Organizational psychology. 3rd Edition, Englewood Cliffs: Prentice Hall.

Scott, W.G., Mitchell, T.R., \& Birnbaum, P.H. 1981. Organization theory: a structural and behavioral analysis. 4th Edition, Homewood, Ill: Richard Irwin.

Seiler, J.A. 1972. Sociotechnical systems. In: Margulies, N. \& Raia, A.P., (eds.), Organizational development: values, process and technology. New York: McGraw-Hill, p. 254-263.

Sheldon, O. 1923. The philosophy of management. London: Pitman.

Stogdill, R.M. 1974. Handbook of leadership: a survey of theory and research. 2nd Edition, New York: Free Press.

Taylor, F.W. 1947. Principles of scientific management. New York: Harper.

Terpstra, D.E. 1981. The organization development evaluation process: some problems and proposals. Human Res. Manage., vol.20, 24-29, Spring.

Thompson, J.D. 1967. Organizations in action. New York: McGraw-Hill.

Tichy, N.M. 1982. Managing change strategically: the technical, political, and cultural keys. Organ. Dynamics, vol.11, 59-80, Autumn.

Watkins, M.L. 1987. Organisasievernuwing: 'n Holistiese benadering. Unpublished Doctoral Thesis. Potchefstroom : Potchefstroom University for C.H.E. 
Westrum, R. \& Samaha, K. 1984. Complex organizations: growth, struggle and change. Englewood Cliffs: Prentice Hall.

Wheelen, T.L. \& Hunger, J.D. 1984. Strategic management. Reading, Mass.: Addison-Wesley.
White, S.E. \& Mitchell, T.R. 1976. Organization development: a review of research content and research design. Acad. Manage. Rev, vol.1, 57-71, Apr.

Woodcock, M. \& Francís, D. 1981. Organization development through teambuilding. Aldershot, Hants: Gower. 